\title{
Breed Effect and Effect of Non-Genetic Factors on Performance Traits of Wool Type Angora Rabbits in an Organized Farm of Kashmir
}

\author{
Nusrat Nabi Khan ${ }^{1}$, A. Hamadani ${ }^{1}$, Eajaz Dar ${ }^{2 *}$, Mir Shabir ${ }^{1}$, Saba Bukhari ${ }^{1}$, \\ Rukhsana Shah ${ }^{1}$, Aadil Ayaz ${ }^{3}$ and Mubashir Ali Rather ${ }^{4}$
}

${ }^{1}$ Division of Animal Genetics and Breeding, Faculty of Veterinary Sciences \& Animal Husbandry, Shere Kashmir University of Agricultural Sciences and Technology of Kashmir, Shuhama, Alusteng, Srinagar, J\&K (India)

${ }^{2} S M S, K V K$, Kargil, SKUAST-Kashmir, India

${ }^{3}$ Department of Biotechnology, School of Life Sciences, Hemvati Nandan

Bahuguna Garhwal University, Srinagar Uttarakhand- 246174, India

${ }^{4}$ Department of Sheep Husbandry, Kashmir, J\&K, India

*Corresponding author

\section{A B S T R A C T}

\section{Keywords}

Angora rabbit, Performance evaluation, Nongenetic factors, Wool

\section{Article Info}

Accepted:

15 May 2020

Available Online:

10 June 2020
Wool produced by Angora Rabbits is considered to be one of finest in the wool and its production is only second to sheep wool and mohair. Production of this fibre is influenced by genetic and non-genetic factors and these bear significant correlations with body weights at different ages. Therefore, the present study was undertaken with the objectives to estimate the performance traits of Angora Rabbits, effect of breed and non-genetic influences on the these performance traits of Angora Rabbits under organized sector in Kashmir. The least squares means were $0.39 \pm 0.02(\mathrm{~kg})$, $0.95 \pm 0.02(\mathrm{~kg}), \quad 2.41 \pm 0.07(\mathrm{~kg}), \quad 454.73 \pm 0.74(\mathrm{gm}), \quad 5.65 \pm 0.04(\mathrm{~cm})$, $2.38 \pm 0.05(\%)$ and $12.29 \pm 0.04(\mu)$ for birth weight $(\mathrm{BW})$, weaning weight (WW), yearling weight (YW), average wool yield (AWY), staple length (SL), medullation percent (MD) and fibre diameter (FD), respectively. The effect of sex, year and season was non-significant on all traits understudy whereas the breed effect was significant on AWY, SL and MD only.

\section{Introduction}

Rabbit farming is practiced for meat, wool, fur, laboratory animal as well as for biological production purposes (Dige et al., 2012). Angora rabbit wool is glossy, soft and much warmer than Angora sheep wool (Pokharna et al., 2004). After sheep wool and mohair, 
angora rabbit wool is third largest animal fibre produced and utilized throughout world with China dominating the international Angora wool market (Schlink and Liu, 2013) and India as marginal producer. The wool production is influenced by genetic and nongenetic factors (Allain et al., 2004). Wool yield bears a positive and significant correlation with different growth traits (Singh et al., 2006; Garcia and Magofk (2010). Qinyu (2012) have reported correlated response between wool yield and body weight traits. The wool yield and body weights at different ages are quantitative traits governed by polygenic inheritance and are influenced by genetic and non-genetic factors (Allain et al., 2004).Exploration of non-genetic factors that influence quantitative traits and correction of records for these factors are important for estimated genetic parameters and breeding value estimation to show the animal's genetic worth (Rashidi et al., 2008). Therefore, the present study was undertaken to study the effect of breed (French and German Angora) and non-genetic factors (sex of animal, year and season of birth) on growth and wool traits of kits born under organized farm conditions.

\section{Materials and Methods}

The data set pertaining to French and German Angora wool type rabbits were collected from Government Angora Rabbit Farm, WusanPattan, District Baramulla, Kashmir for the present study. The data were collected from flock books, body weight and wool record registers maintained at two sheep breeding farms. The information was collected on animal number, sire, dam number, date of birth, birth weight, weaning weight\& yearling body weight and annual wool yield from flock books, body weight and wool record registers. Data regarding fiber diameter, medullation percent and staple length were collected from wool analysis reports conducted at fleece testing laboratory Nowshara, Srinagar. The data were classified to study the effect of breed (French and German Angora) and nongenetic factors like years (2009, 2010 and 2011), gender (Male, Female), and season (Spring, Summer, Autumn and Winter).In order to overcome non-orthogonality of the data due to unequal subclass frequencies, multivariate general linear modal function of SPSS was used to analyze the data with breed (1 to 2 ), gender (1 to 2 ), year (1 to 3 ) and season (1 to 4) as fixed effects. The model adopted for data analysis was, $Y_{i j k l m}=\mu+B_{i}+Y_{j}+S_{k}+G_{1}+e_{i j k l m}$ where, $Y_{i j k l m}$ is the observation of $m^{\text {th }}$ lamb of $1^{\text {th }}$ sex, born in $\mathrm{k}^{\text {th }}$ season and $\mathrm{i}^{\text {th }}$ year of $\mathrm{j}^{\text {th }}$ genetic group. $\mu$ is overall mean, $B_{i}, Y_{j}, S_{k}$ and $G_{l}$ is fixed effects of breed, year of birth, season of birth and sex of animal, respectively. $\mathrm{e}_{\mathrm{ijklm}}$ is error associated with each observation and was assumed to be normally and independently distributed with mean zero and variance $\sigma^{2}{ }_{\mathrm{e}} \mathrm{N}$ $\left(0, \sigma_{\mathrm{e}}^{2}\right)$.

The statistical significance of various fixed effects in the least squares model was determined by ' $\mathrm{F}$ ' test.

\section{Results and Discussion}

The least squares means were $0.39 \pm 0.02(\mathrm{~kg})$, $0.95 \pm 0.02(\mathrm{~kg}), 2.41 \pm 0.07(\mathrm{~kg}), 454.73 \pm 0.74$ $(\mathrm{gm}), \quad 5.65 \pm 0.04 \quad(\mathrm{~cm}), \quad 2.38 \pm 0.05 \quad(\%)$ and12.29 $\pm 0.04(\mu)$ for birth weight $(\mathrm{BW})$, weaning weight (WW), yearling weight (YW), average wool yield (AWY), staple length (SL), medullation percent (MD) and fibre diameter (FD), respectively. Similar estimate of weaning weight were reported by Adelodun (2015) in four breeds of rabbits whereas Siva-kumar et al., (2013) found 0.5 $\mathrm{kg}$ birth weight and 0.6-0.7 $\mathrm{kg}$ weaning weight in Soviet Chinchilla. Ghosh et al., (2008) in New Zealand White and Soviet Chinchilla found weaning weight and adult weight of $0.6-0.7 \mathrm{~kg}$ and $1.8-1.9 \mathrm{~kg}$, respectively. 
Table.1 Least squares means (+SE) and tests of significance of factors affecting body weight of rabbit in Kashmir

\begin{tabular}{|c|c|c|c|c|c|c|c|c|}
\hline Particulars & $\mathbf{N}$ & BW (kg) & WW (kg) & YW (kg) & AWY (gm) & $\mathrm{SL}(\mathrm{cm})$ & MD (\%) & FD $(\mu)$ \\
\hline Overall & 202 & $0.39 \pm 0.02$ & $0.95 \pm 0.02$ & $2.41 \pm 0.07$ & $454.73 \pm 0.74$ & $5.65 \pm 0.04$ & $2.38 \pm 0.05$ & $12.29 \pm 0.04$ \\
\hline P. value & & $(0.457) \mathrm{N}$ & $(0.077) \mathrm{N}$ & $(0.753) \mathrm{N}$ & $(0.736) \mathrm{N}$ & $(0.482) \mathrm{N}$ & $(0.959) \mathrm{N}$ & $(0.860) \mathrm{N}$ \\
\hline Spring & 107 & $0.40 \pm 0.01^{\mathrm{a}}$ & $0.96 \pm 0.02^{\mathrm{a}}$ & $2.46 \pm 0.07^{\mathrm{a}}$ & $455.33 \pm 0.69^{\mathrm{a}}$ & $5.68 \pm 0.04^{\mathrm{a}}$ & $2.36 \pm 0.05^{\mathrm{a}}$ & $12.30 \pm 0.04^{\mathrm{a}}$ \\
\hline Summer & 24 & $0.37 \pm 0.02^{\mathrm{a}}$ & $0.98 \pm 0.02^{\mathrm{a}}$ & $2.44 \pm 0.08^{\mathrm{a}}$ & $455.06 \pm 0.84^{\mathrm{a}}$ & $5.59 \pm 0.05^{\mathrm{a}}$ & $2.38 \pm 0.06^{\mathrm{a}}$ & $12.33 \pm 0.05^{\mathrm{a}}$ \\
\hline Autumn & 8 & $0.39 \pm 0.04^{\mathrm{a}}$ & $0.90 \pm 0.04^{\mathrm{a}}$ & $2.29 \pm 0.18^{\mathrm{a}}$ & $454.35 \pm 1.80^{\mathrm{a}}$ & $5.65 \pm 0.10^{\mathrm{a}}$ & $2.38 \pm 0.13^{\mathrm{a}}$ & $12.25 \pm 0.10^{\mathrm{a}}$ \\
\hline Winter & 63 & $0.39 \pm 0.02^{\mathrm{a}}$ & $0.98 \pm 0.02^{\mathrm{a}}$ & $2.44 \pm 0.10^{\mathrm{a}}$ & $454.19 \pm 0.99^{a}$ & $5.67 \pm 0.06^{\mathrm{a}}$ & $2.40 \pm 0.07^{\mathrm{a}}$ & $12.28 \pm 0.06^{\mathrm{a}}$ \\
\hline P. value & & $(0.822) \mathrm{N}$ & $(0.091) \mathrm{N}$ & $(0.459) \mathrm{N}$ & $(0.966) \mathrm{N}$ & $(0.479) \mathrm{N}$ & $(0.977) \mathrm{N}$ & $(0.764) \mathrm{N}$ \\
\hline 2009 & 86 & $0.38 \pm 0.01^{\mathrm{a}}$ & $0.97 \pm 0.01^{\mathrm{a}}$ & $2.48 \pm 0.05^{\mathrm{a}}$ & $454.55 \pm 0.55$ & $5.66 \pm 0.03^{\mathrm{a}}$ & $2.38 \pm 0.04^{\mathrm{a}}$ & $12.31 \pm 0.03^{\mathrm{a}}$ \\
\hline 2009 & 69 & $0.38 \pm 0.01^{\mathrm{a}}$ & $0.94 \pm 0.01^{\mathrm{a}}$ & $2.48 \pm 0.06^{\mathrm{a}}$ & $454.62 \pm 0.59$ & $5.69 \pm 0.03^{\mathrm{a}}$ & $2.37 \pm 0.04^{\mathrm{a}}$ & $12.32 \pm 0.03^{\mathrm{a}}$ \\
\hline 2009 & 47 & $0.39 \pm 0.04^{\mathrm{a}}$ & $0.96 \pm 0.04^{\mathrm{a}}$ & $2.27 \pm 0.18^{\mathrm{a}}$ & $455.04 \pm 1.82$ & $5.60 \pm 0.10^{\mathrm{a}}$ & $2.39 \pm 0.13^{\mathrm{a}}$ & $12.25 \pm 0.10^{\mathrm{a}}$ \\
\hline P. value & & $(0.952) \mathrm{N}$ & $(0.933) \mathrm{N}$ & $(0.782) \mathrm{N}$ & $(0.000) * *$ & $(0.000)^{* *}$ & $(0.000)^{* *}$ & $(0.174) \mathrm{N}$ \\
\hline French Angora & 127 & $0.39 \pm 0.01^{\mathrm{a}}$ & $0.95 \pm 0.02^{\mathrm{a}}$ & $2.42 \pm 0.07^{\mathrm{a}}$ & $303.65 \pm 0.67 a$ & $5.13 \pm 0.04^{\mathrm{a}}$ & $2.24 \pm 0.05^{\mathrm{a}}$ & $12.27 \pm 0.04^{\mathrm{a}}$ \\
\hline German Angora & 75 & $0.39 \pm 0.02^{\mathrm{a}}$ & $0.95 \pm 0.02^{\mathrm{a}}$ & $2.40 \pm 0.09^{\mathrm{a}}$ & $605.82 \pm 0.93 b$ & $6.17 \pm 0.05^{b}$ & $2.53 \pm 0.07^{b}$ & $12.32 \pm 0.05^{\mathrm{a}}$ \\
\hline P. value & & $(0.459) \mathrm{N}$ & $(0.677) \mathrm{N}$ & $(0.629) \mathrm{N}$ & $(0.405) \mathrm{N}$ & $(0.428) \mathrm{N}$ & $(0.907) \mathrm{N}$ & $(0.644) \mathrm{N}$ \\
\hline Male & 109 & $0.38 \pm 0.02^{\mathrm{a}}$ & $0.96 \pm 0.03^{\mathrm{a}}$ & $2.38 \pm 0.11^{\mathrm{a}}$ & $454.32 \pm 1.09 a$ & $5.63 \pm 0.06^{\mathrm{a}}$ & $2.38 \pm 0.08^{\mathrm{a}}$ & $12.28 \pm 0.06^{\mathrm{a}}$ \\
\hline Female & 93 & $0.39 \pm 0.01^{\mathrm{a}}$ & $0.95 \pm 0.01^{\mathrm{a}}$ & $2.43 \pm 0.06^{\mathrm{a}}$ & $455.15 \pm 0.64 a$ & $5.67 \pm 0.04^{\mathrm{a}}$ & $2.39 \pm 0.05^{\mathrm{a}}$ & $12.31 \pm 0.04^{\mathrm{a}}$ \\
\hline
\end{tabular}


Table.2 Phenotypic correlation among performance traits of Angora rabbits

\begin{tabular}{|l|l|l|l|l|l|l|l|}
\hline & BW & WW & YW & AWY & SL & MD & FD \\
\hline BW & 1 & & & & & & \\
\hline WW & 0.31 & 1 & & & & & \\
\hline YW & 0.23 & $0.23^{* *}$ & 1 & & & & \\
\hline AWY & 0.02 & -0.01 & 0.01 & 1 & & & \\
\hline SL & 0.04 & -0.05 & -0.01 & $0.92^{* *}$ & 1 & & \\
\hline MD & -0.05 & -0.05 & -0.01 & $0.46^{* *}$ & $0.44^{* *}$ & 1 & \\
\hline FD & -0.07 & -0.01 & -0.02 & 0.13 & 0.11 & 0.03 & 1 \\
\hline
\end{tabular}

Olonofeso et al., (2012) reported BW and WW of $0.3-0.4 \mathrm{~kg}$ and $2.1-2.2 \mathrm{~kg}$, respectively in three breeds of rabbits. Khalil et al., (2013) in Baladi Red and New Zealand White estimated adult weight of 2.2 to $2.5 \mathrm{~kg}$. More or less similar estimates of $335.7 \pm 26.2$ gm and656.4 $\pm 161.0 \mathrm{gm}$ and $949.6 \pm 101.1$ $\mathrm{gm}$ of average wool yield in British Angora and Chinese Angora, respectively were reported by Neupane et al., (2010). However, higher estimates of $775.75 \pm 20.45 \mathrm{gm}$ and $949.6 \pm 101.1 \mathrm{gm}$ of AWY in German Angora rabbit were observed by Singh et al., (2006) and Neupane et al., (2010), respectively. More or less similar estimates of BW, WW, YW, AWY, SL, MD and FD were found by Assad et al., (2017) in French Angora and German Angora rabbit breeds. The effect of season on performance traits of rodents accounts for variation in weather conditions in terms of temperature, humidity and may be mediated through availability of quantity and quality of feed and fodder. The effect of season was observed non-significant on all the traits under study. Contrary to the results of present study Ghosh et al., (2008) and Dige et al., (2012) in New Zealand White rabbit found significant variation in body weight traits due to season of birth. The year effect is due to variation in management practices, knowledge and/ or experience of the farm manager and workers and facilities available on the farm. However, the effect of year of birth was non-significant in the present study and may be attributed to similar management provided to rodents by same experienced workers for the three years under study. The effect of sex was non-significant on all the traits and in consonance with Ghosh et al., (2008) and Assad et al., (2017). On the contrary, significant effect of sex on wool yield in Angora rabbit was reported by Sood et al., (2007). The effect of breed was highly significant ( $p>0.01)$ on AWY, SL and MD whereas non-significant on BW, WW, YW and FD. Ghosh et al., (2008) also reported non-significant effect of breed on individual weaning weight of local rabbits of subtropical climate. Contrary to the result of the present study Egena et al., (2012) reported significant effect of breed on live litter bodyweight of Rabbit in Minna, Niger State, Nigeria. Chineke (2005) reported significant effect of genotype and non-significant effect of sex on individual kit weight in rabbit breeds and thier crosses. On contrary, breed having nonsignificant effect on individual weaning weight on local rabbits of subtropical climate were reported by Ghosh et al., (2008). Neupane et al., (2010) and Assad et al., (2017) also observed significant effect of breed on AWY, SL and MD and nonsignificant effect on FD.

The phenotypic correlations between performance traits are presented in Table 2. The phenotypic correlations between body weight traits were positive in direction and 
low to moderate in magnitude. The positive correlations between growth traits suggest that the traits are under the same gene action (Pleiotropy). Chineke (2000), Tiamiyu et al., (2000) and Abdullah et al., (2003) also reported positive phenotypic correlations among different growth traits in different rabbit breeds. The phenotypic correlation of AWY was positive and high with SL and MD. The phenotypic correlation of body weight traits was usually negative with wool quality traits. Similarly, phenotypic association between MD and FD was negative. The positive correlations among growth traits and positive correlation with annual wool yield as well as their negative relationship with wool quality (FD, SL and MD) traits obtained in the present study indicated that increase in body weight would result in corresponding improvement in other traits also.

In conclusion, the breed possesses significant of variation for wool yield, staple length and medullation (\%). whereas year, sex and season had non-significant effects on the performance traits of wool type rabbits. The phenotypic association between body weight traits was observed negative. The present study will provide bases for genetic manipulation and improvement of rabbits in temperate conditions of Kashmir.

\section{References}

Abdullah, A. R., Sokunbi, O. A., Omisola, O. O. and Adewumi, M. K. (2003). Interrelationships between body weight and linear body measurements in domestic rabbit (Oryctolagus cuniculus). Proceedings of the 28th Annual Conference of Nigerian Society for Animal Production, 28, 133-136

Adelodun, O. F. (2015). Evaluation of post weaning morphometric traits among four breeds of rabbits in humid tropics. Global Journal of Animal Breeding and
Genetics, 3, 2408-5502

Allain, D., Rochambeau, H. D., Thebault, R. G. and Vrillon, J. L. (2004). The inheritance of wool quantity and live weight in the French Angora rabbit. Animal Science, 68, 441-447

Chineke, C. A. (2000). Characterization of physical body traits of domestic rabbit in humid tropics. Proceedings of 25th Annual Conference of Nigerian Society for Animal Production, 25, 237-239.

Chineke, C.A. (2005). Genetic and nongenetic effects on weaning and post weaning traits in rabbit breeds and thier crosses. Pakistan Journal of Biological Sciences, 10, 1402-1410

Dige, M. S., Kumar, A., Kumar, P., Dubey, P. P. and Bhushan, B. (2012). Estimation of variance components and genetic parameters for growth traits in New Zealand White rabbit (Oryctolagus cuniculus), Journal of Applied Animal Research, 40-2 (6), 16-172.

Egena, S. S. A., Akpa, G. N., Alemede, I. C. and Aremu, A. (2012). Genetic and Non-genetic factors affecting litter size and birth weight of rabbit in Minna, Niger State, Nigeria. SSA Animal Production, 14(3), 160- 166,

Garcia, F. X. and Magofke, J. C. (2010). Genetic parameters for the production of fleece and body weight in Angora rabbits. Adv Prod Anim., 12, 81-90

Ghosh, S. K., Das, A., Bujarbaruah, K. M., Das, A., Dhiman, K. R. and Singh, N. P. (2008). Effect of breed and season on rabbit production under subtropical climate. World Rabbit Science, 16, 2933

Khalil, M. H. E., Owen, J. B. and Afifi, E. A. (2013). A review of phenotypic and genetic parameters associated with meat production traits in rabbits. Animal Breed Abstract, 54, 726-749

Neupane, D., Dhaubhadel, T. and Prashad, S. R. (2010). Evaluation of Wool 
Production Performance on Different Lines and Strains of Angora Rabbit at Khumaltar, Lalitpur. Nepal Journal of Science and Technology, 11, 83-86

Olonofeso, O., Adejuwon, A. J., Ademokoya, V. A. and Durosaro, S.O. (2012). Breeding and Productive Performance of Three Breeds of Rabbit in SouthWest Nigeria. Global Journal of Science Frontier Research Bio-Tech \& Genetics, 12, 0975-5896

Pokharna, A. K., Gupta, N. P., Patni, P. C., Arora, R. K. and Shakyawar, D. B. (2004). Processing of Angora Rabbit Wool and Cashmere Production \& Utilization. Pp. 166-73. 25-26th September 2004. Manali (H.P.).

Qinyu, M. (2012). Studies on method of early selection and early mating in German Angora rabbits. Journal of Applied Rabbit Research, 15, 322-328

Rashidi, A., Mokhtari, M.S., Jahanshahi, A.S. and Abadi, M.M. 2008. Genetic parameter estimates of pre-weaning growth traits in Kermani sheep. Small Ruminant Research, 74(1), 165-171.

Schlink, A. C. and Liu, S. M. (2013). Angora rabbits: A potential new industry for Australia. RIRDC Publication No.03/014. RIRDC, Australia.

Singh, U., Sharma, S. R., Bhatt, R. S., Kumar, D. and Risam, K. S. (2006). Effect of shearing intervals on the growth and wool parameters of German Angora rabbits. Indian Journal of Animal Science, 76, 88-91

Sood, A., Gupta, K., Risam, K. S., Katoch, S. and Kaila, O. P. (2010). Non-genetic factors affecting wool yield in angora rabbits. Indian Journal of Animal Research, 41 (3), 0367-6722

Tiamiyu, A. K, Raji, A. M., Babatunde, B. B. and Hamzat, R. A. (2000). Interrelationship among live body measurements in medium breed rabbits. Proceedings of 25th Annual Conference of Nigerian Society for Animal Production, 25, 252-253.

\section{How to cite this article:}

Nusrat Nabi Khan, A. Hamadani, Eajaz Dar, Mir Shabir, Saba Bukhari, Rukhsana Shah, Aadil Ayaz and Mubashir Ali Rather. 2020. Breed Effect and Effect of Non-Genetic Factors on Performance Traits of Wool Type Angora Rabbits in an Organized Farm of Kashmir. Int.J.Curr.Microbiol.App.Sci. 9(06): 676-681. doi: https://doi.org/10.20546/ijcmas.2020.906.086 